Gabriela Abrasowicz

University of Silesia

Katowice

Poland
UDC 792(497.1)

doi: 10.5937/ZbAkU2008016A

Original scientific paper

\title{
Transcultural Hybridity in the Post-Yugoslav Theater ${ }^{1}$
}

Abstract: The post-Yugoslav macro-region is a dynamic and complex zone, where contemporary tensions between cultural homogenization and cultural heterogenization are manifested. It contains an idiom of multilingualism, multi-ethnicity, multi-religiosity, and complicated identity and dependability processes. Following the enforced 'existence alongside' under the Yugoslav federation, and its breakup afterwards, productive negotiations, 'existence together' and even co-creation were restored. It is particularly noticeable in theater which involves meeting and interaction. At the beginning of the twenty-first century in the area of former Yugoslavia, the phenomena confirming transcultural close-contact practices within this (hyper)production are becoming more frequent. Indeed, the interpenetration of cultures; networking; the circulation of creative, aesthetic and philosophical ideas growing out of different cultural backgrounds; the physical mobility of artists; the use of modern communication channels; as well as translation lead to the production of new, hybrid qualities.

Currently, an increasing number of such forms of public theater expressions may be observed in the region; they arise in consequence of interference of cultures, bonding of a documentary and fiction, they are intermedial, mobile, multilingual, and fluctuate between the zone of art and social life. Experimental stage projects created by Milena Bogavac and Kokan Mladenović (from Serbia) or Jeton Neziraj (from Kosovo) and also performances directed by Borut Šeparović (from Croatia), Jernej Lorenci (from Slovenia), Selma Spahić and Dino Mustafić (from Bosnia and Herzegovina) seem to be a medium particularly predestined for exploration of the problem of identity hybrid, projected, performative, contextual, adaptative, and made precise in relations to the Otherness. Hence, they challenge official, homogenizing discourses. The term 'hybridity' will mean here a metaphor - a formal structure which constitutes a blend of cultural codes and a combination of diverse models of creative expression.

In response to the demand for finding an adequate interpretation key for these processes, the methodological skills shall be enriched by the category of transculturality proposed by Wolfgang Welsch, a German theoretician of postmodernism. This option contains a modern vision of open culture which generates artistic proposals requiring a specific type of reception.

Keywords: hybridity, transculturality, theater, post-Yugoslav region, identity.

1 The text is an outcome of research project No. 2017/24/C/HS2/00436, financed by the National Science Centre, Poland. 


\section{Introduction}

A specific dynamics and direction of changes in theatrical production, which in the last quarter of the century may be noticed in the area of the former Yugoslavia countries, lead to a multifaceted extension: range of transborder interferences, form and context of the artistic expression, range of cooperation network, and methodology of interpretation. Progressing processes of extension and development on the level of culture and art enforce unstiffening of the current research perspective. In response to the demand for finding a more adequate method to analyse the text transfer, styles of acting, flexible rules, or specific solutions which lead to emergence of not-yet formed phenomena, a transcultural theory notably developed and popularized by German philosopher Wolfgang Welsch shall be taken into consideration.

It is undeniable that cultures have never functioned in isolation. Each of them is characteristic of lesser or greater internal diversity and external connections. However, a mosaic picture of the post-Yugoslav region is the reflection of one of the key issues of the present - the tension between cultural homogenization and cultural heterogenization and the globally binding idiom of multilingualism, multiethnicity and multiconfessionality, complex identity processes and dependencies.

In the case of the area I am interested in, a special type of transposition process of creative, aesthetic, philosophical ideas within various structures may be spoken of. Initially, 'being beside one another' (times when Yugoslavia existed) was enforced, then came the stage of breakup and emphasizing individuality (Balkanization, formation of new countries) and recently the idea of 'being together' (networking in the culture sector) has been predominant. The concept of transculturality defined as the ,consequence of the inner differentiation and complexity of modern cultures [...], which also interpenetrate or emerge from one another" (Welsch, 1999: 101) ${ }^{2}$ assumes that cultures transform into interrelated networks through migration, complex global and local communication systems, economic and political relations. In consequence, it primarily leads to hybridization of culture. The area of former Yugoslavia is a specific laboratory of such cultural processes.

Wolfgang Welsch claims that hybridization marks contemporary cultural transformations because „for each culture, all other cultures have gradually become internal content or their satellites. This process occurs at the level of population, trade, information and art"(Welsch, 1998: 205). The presented theoretical approach is covered

\footnotetext{
2 The concept of transculturality is different from transculturation (coined by Cuban anthropologist Fernando Ortiz in the 1940s to offer an important alternative to 'acculturation'), multiculturalism understood as cohabitation of multiple cultures and organization of space in a sort of peaceful coexistence, and interculturality - defined as existence of cultural identities with stable references, with tolerance and promotion of dialogue between them. (see also Deardorff, 2008: 32-52).
} 
by the term 'transaesthetics', which also calls for adopting the concept that currently we are facing the formation of a 'network of transcultural identities' which is of a hybrid nature (Welsch, 2004: 34).

Let us point out that observation of theatrical artists in the post-Yugoslav region in the last decade allowed us to notice numerous manifestations of cultural mobility the circulation of people, material objects, concepts and signs (Greenblatt, 2009). It is also of importance that many projects are performed at transnational level through co-production, cooperation and exchange. ${ }^{3}$ In this case, transcultural strategies have different backgrounds. The first type is related to economic conditions. The reason for the co-production is external, financial, which can lead to a certain kind of universality in both narrative and aesthetic-formal sense. The other strategy is based on creating a transnational space serving as a contact zone. The spread of cultural syncretism has broken down aesthetic boundaries. The principles of cultural hybrids functioning are transferred to the level of creation, which more and more often consists in moving away from formal thinking about the artistic image and 'presentational values' (Crimp, 1980).

On a general level, hybridisation refers to producing a blend of phenomena, which are perceived as different and individual, hence this term applies to the process of going beyond a category, and therefore creation of a new aesthetics, also theatrical. Hybridization assumes that originally certain elements used to be separate, they do not fit to one another in a natural way and were arbitrarily connected. However, it is difficult to precisely determine whether an intervention from the outside into natural bonds and relations of art took place or not. In the opinion of Erika Fischer-Lichte, it seems more adequate to use of the term 'hybridity' as a metaphor rather than precisely defined concept. Director of the International Research Centre on „Interweaving Performance Cultures" at Freie Universität Berlin (since 2008) observed that the term 'hybrid' properly referred to the conjunction of different and often unlike species in biology, suggesting that its application to cultural processes was therefore inappropriate. Hence the turn to 'interweaving', a term drawn from textile crafts, to indicate the interrelation but distinctness of plural strands (Fischer-Lichte, 2010). It can be used synonymously in theoretical discussion to mean the mixing of materials and combination of patterns in contrast to hierarchy and hegemony (Fischer-Lichte, 2014).

Therefore, a hybrid will here be construed as a formal structure which constitutes a blend of cultural codes, a combination of diverse models of creative expression and

3 It should also be added that the promotion of unity through culture was noticeable earlier. In 1977, Serbian director Ljubiša Ristić formed a theater troupe called „KPGT“ (Kazalište Pozorište Gledališče Teatar - the first letters of the words for 'theater' in four Yugoslav languages, in Croatian, Serbian, Slovene, and Macedonian). It engaged actors and playwrights from all republics in creating intercultural projects. Ristic says that the idea was to collect ,the diversity [of Yugoslavia] in a unified cultural space, to preserve these differences which were the richness of society." (see also Balakijan, 2019). 
providing an increasingly pervasive mode for cultural engagement. Hybridization embraces production processes, cultural spaces, intertexts, media, and it is viewed as a kind of ,aggregate of multiple influences and sources“ (Heiser, 2010: 35). This means constructing a new, enriched sphere of negotiations and representations (Rewers, 2003) and extending a range of theatrical production at the level of form and content. The latest history of Balkans shows that such actions are not obvious and automatic at all. However, it shall not be forgotten that evolution of theater has always been a result of continual exchange with theatrical styles of other cultures - most often the neighbouring ones, sharing many common characteristics and developing in similar conditions.

Recently several projects have been made in the region, which do not come down to mere fact of translation or interpretation. Adopted strategies of cooperation, exchange and co-production enable creation of few qualities and formation of bridges. In these territories, the dissemination of artistic forms described as hybrid, combining not only different types of artistic expression, but also procedures characteristic for the area of scientific research, designing new technologies or philosophical reflections and political actions is more and more noticeable (Chaberski, 2016).

Among regional projects it is easy to find those which exceed the framework of one, traditionally observed order. The transcultural theory postulates perceiving them in a different way. The most representative examples of conjunctions of actions related to revision of history, memory and identity, as well as, problematization of mode of creation and representation are evoked here. The below presented categorization serves to present what characteristics may dominate in them. However, it should be borne in mind that the proposed division of works resulting from the interweaving of measures which blur the established boundaries, is conventional and one of the possible.

\section{Adaptation}

One of the most characteristic determinants of the contemporary post-Yugoslav theater is adaptation, not only of the text, but also of various artefacts and cultural orders, social elements and practices. The prefigurative techniques and re-narrations in relation to the famous texts of culture are important elements in creation of theater shows. Staging as a simple transposition is however, superseded by complex processes of revitalization and recontextualization. A text, which is a starting point, is often subject to a profound transformation, reorganization of individual elements, with possible reduction, concentration, ,inclusion of texts other than plays, editing of non-textual elements, modification of the ending or conclusion, changes of plot made due to the requirements of stage discourse" (Pavis, 1998: 21). The most interesting effects are gained if a particular text is transposed into a different cultural background and worked on by artists who are 
unrooted in a given culture, potentially uninvolved. However, the process of creation reveals certain interfaces and possibilities of transposing specific content to a new ground.

The status of the literature (but also other source texts of culture) as a source has changed and that is of importance here. It is treated as a material and opens theater not only to a network of intertexts, but also to a variety of contexts: social, communication, political, medial. The performative facet of literature as a discourse displayed (not only imagined), initiating a space for actions and intervention is emphasized (Sordyl, 2011).

It is worth paying attention to the integrating project Romeo and Juliet (Romeo i Julija/Romeo i Zhulieta, 2016) directed by Miki Manojlović, made as a Serbian and Kosovan co-production. The story, based on Shakespeare's play, perfectly shows deep divisions and conflicts which still pose some problems in that part of the Balkan peninsula. However, the play is focused on the possibilities of dialogue. The story of tragic love between two lovers from feuding Italian families is placed in our contemporary reality. The main subject of the play includes hatred and the ability to learn, understand, and be with each other, and not only stay side by side. The project was executed in cooperation between Integration Workshop from Belgrade and Multimedia Center from Pristina, and gathered actors from Pristina, Belgrade, Sombor, Sarajevo and New York.

The division of roles is significant. Romeo and the roles of the Montague family are usually played by Kosovan actors, whereas Juliet and the Capulets - by Serbian artists. Such a choice can be interpreted as a transmission of local conflicts. The artists on stage, regardless of their nationality, have lines both in Albanian and Serbian which intermingle and complement one another, showing that, in spite of all that, communication is still possible.

The constellation of sources, not only literary, became the foundation of a Croatian production in 2019 - Eichmann in Jerusalem (Eichmann u Jeruzalemu, 2019) directed by Jernej Lorenci. The Slovenian artist, who defined himself as a coordinator rather than a director, supervises the construction of a multithreaded story about the problems of the holocaust and banality of evil, which is not so distant in time and space from the everyday life of the Croats. The structure is largely based on borrowings from various texts of culture: Hannah Arendt's essay, Claude Lanzmann's documentary Shoah, Jaspers's collection of lectures published in The Question of German Guilt, Boris Pahor's book Necropolis, Curzio Malaparte's novel The Skin and Stanley Kramer's feature film Judgement at Nuremberg. The zone of presentation is stretched among references to these works, objective facts and the subjective experience of reality. The adopted convention has such an effect that expectations which accompany following of the adapted fiction get shattered. The actors admit that preparations for the performance were a demanding research process. They brought their texts, etudes, 
drafts and monologues and analyzed performativity of historical events and episodes from their own lives.

The play begins in a documentary tone, the actors discover the tricks of the trade, allow themselves humorous interjections, share their own observations on the text, provide detailed information from the biography of the Nazi criminal, and then reconstruct fragments of prisoners' testimony, revive images from Jewish ghettos and concentration camps and describe Eichmann's trial in Jerusalem from the courtroom, his appearance and behaviour. In the second part, the performance moves to a local or even personal level. The intertwining between the collective and the individual becomes exposed. The Croatian context is presented thanks to the figure of the criminal (Andrija Artuković), also during his trial. And again, there is a transition from the public to the private sphere thanks to a series of confessional statements made by the actors (the artists evoke memories and tragic facts about their families), inducing compassion and sense of involvement. Lorenci gave the group which was responsible for expanding the material base the possibility of blurring the border between different orders, thanks to which the group moves away from theatrical ritualism.

\section{Media}

Theater shows produced in consequence of deconstructing the classical modern model are also an important factor, impacting transformations in theater. This 'new or newer theater' means an approval for intermingling different disciplines and elements, taking from different segments of art (Borowski et al., 2012). This means among others the introduction of mediating, old and new, forms of media. It is difficult to imagine contemporary theater without multimedia, converging of media and art forms, blending and blurring the lines between the visual, aural and literary art forms. At first, it was a question of inspiration, later - of an impact on the theatrical aesthetics, and today theater and multimedia act in partnership. Theater, due to time and space constraints related to the communication process does not compete for domination with the audio-visual or virtual media, but it expands and transforms its own conventions. Besides, the rules of theater funding and expansion more and more often enforce the need for technical reproduction. In the post-Yugoslav theatrical productions, the space for experimenting with media and models of production, presentation and participation is continuously broadening, although these actions may not be called revolutionary or radical. This theater imports some technologies and related strategies (editing, cropping, screening) and at the same time it seeks and enhances its specific, bodily characteristics established by the presence of actor and co-presence of spectator. 
A Serbian production Jami District (Jami Distrikt, 2017) is an example of the accumulation and interweaving of various means of expression. The creators by their action have confirmed that ,theatre is an integrative, collaborative art which potentially and sometimes actually includes all art. Also, digital media have had a significant impact on performance practice and scholarly thinking about theatre" (Fischer-Lichte, 2014: 159). Director Kokan Mladenović and dramaturge Minja Bogavac decided to make an interesting juxtaposition of images, objects, media, art and technology, but also people and nonhuman factors. An important landmark of this show is the screen, on which the projections appear. Elements of concert, video clip, quiz show, commercial, TV news, speeches, talk, ring fight, and stand-up comedy may be found in the structure of this show which is jokingly referred to as a documentary theater performance about the oldest nation in the world. This is a play that questions the issues of the nation and national country in the hi-tech world of the $21^{\text {st }}$ century. The premise of the performance is the fictional (but wholly possible) event of the discovery of humanity's oldest Palaeolithic settlement in the village of Jamena at the tripoint border between Serbia, Croatia and Bosnia and Herzegovina. The question of who owns the discovery creates a dispute, which leads to a war between the three countries. The script that Bogavac wrote after brainstorming and improvisation may seem exaggerated and absurd, but it is highly plausible.

In the art project called Between the Walls (Med zidima, 2019) a projection on screen has a completely different status, purpose and dynamics. The authors $-\mathrm{a}$ Croatian organization Gllugl and a Bosnian director Selma Spahic address the issue of non-identification of ordinary people with marginalized and exterminated persons. Everyday life of the whole community is disturbed by tragic and traumatic events, but the performance shows that it was normal for families to lock themselves within the four walls of their comfort, as if what functions in the collective memory as a historical fact did not concern them at all.

The starting point for this venture is the story of the Eldan family, the founders of Gllugl. The director decided on an interesting technical solution that allows to move from construction to deconstruction, to expose the problem and to update it while simultaneously taking it out of the local context. On the wall closing the stage, a film is projected - one of the sets - recorded in the living room of the Eldan family's authentic apartment, where several women live a humdrum routine life. It's a pretty hermetic space. At their own request, they are practically out of the reach of any signs from the outside, the walls isolate them from events such as warfare, disappearances of neighbors, dismissal of workers, restrictions, deportation of people of Jewish origin.

The recorded scenes are synchronized with the play (spoken lines and movements) of the same actors whom the audience can observe directly on stage. However, this is not a mere transfer or reflection. One can immediately see a certain 
stratification here, for example by the set design and costumes from different epochs (old, stylish furniture and outfits on the screen, and freedom and modernity on stage). We deal with different orders - there and then - here and now, passivity - activity, artificiality - reality.

The coordination, which makes the viewers realize that change and progress are impossible, is at some point disturbed, the actors break out of the conformist rhythm. These two worlds cease to be parallel. The clash - when the recording continues and actors on stage come out of the roles played so far and express themselves in their own name - has such an effect that the applied concept has not worn out or trivialized. Actors refer directly to specific, current political facts, presenting quotes and names of public persons. In this way, they expose and criticize the contemporary attitude of people who reject consciousness and responsibility for harming others.

Vital themes and an interesting study combining various artistic disciplines and media as well as social engagement are the hallmark of the Croatian group called MONTAЖ\$TROJ. Borut Šeparović's projects involve among others interventions in fossilized cultural patterns. The latest proposal realized in cooperation with the Zagreb Youth Theater and Academy of Dramatic Art in Zagreb - the play Youth Without God (Mladež bez Boga, 2019) originated from two texts: a dark novel of the same title (Jugend ohne Gott, 1938) by Ödön von Horváth and a book Herons: Mass Murder and Suicide (2015) by Franco 'Bifo' Berardi. These main threads - descriptions of growing fascism and the scene of preparations for war taken from the Austrian writer's work and the Italian Marxist's reflections on the 'school-shooting' phenomenon are intertwined with documentary material, manifestos, records of Anders Breivik's testimony, content taken from web portals, camera recordings, dark web resources, Doom screenshots, photos from Snapchat and Face Swap. It is interesting how well the director managed to transpose elements of a distant reality into his native, very concrete ground and how he succeeded in touching critical issues of Croatian everyday life. The director exposes a generation of apathetic, self-centred individuals seduced by the idea and imperative of new individualism. Young people prepare for the war in the context of the STEM revolution (Science, Technology, Engineering, Mathematics) and lose contact with traditional social values such as solidarity and tolerance. The multimedia, intertextual story in Šeparović's version invites reflection on social Darwinism and is an attempt to outline a certain state of mind. The audience must judge for themselves whether there is still any hope for saving young people and the rest of society.

\section{Memory as the Basis of Identity}

In theater shows produced by artists from the post-Yugoslav region an element of problems with identity may also be found. Disappearance from the map of a federated country and globalization processes led - on the one hand to intensification of nationalism, 
but on the other hand - to dilution of national identity. The main factors which are to foster construction of identity on the basis of sharp intercultural boundaries are national and religious narrations. They are based on uniformization of groups and rigid group divisions into 'we' and 'they' (Golka, 2010). Deconstruction of identity combined with transnational mobility may be the main factor triggering the transcultural approach.

In many theatrical shows, identity is a specific principle of the world order, which is located at the crossing of subjects and social structures, subjectivity and objectivity, choices and dictation, self-reflectiveness and social experiences. The creators however, seem to be asking a question whether identity may be formed in any structure of any elements? What position shall be taken towards obscurity and hybridity of identity or its incomplete defining, or even lack? Another discussed subject is the status of outrooted, drifting, mobile individuals and also 'dregs of society' as a peculiar cultural hybrid which shares the characteristics and cultural values of two dissimilar groups, most frequently old and new or dominated and dominating.

Theoreticians reflect however, that the term 'identity' is in itself burdened with polysemy, and in the age of transformations in the area of local-global, centerperipheries, it would be advisable to use more precise concepts, such as: identifications and categorizations, auto-comprehension and social location, commonality (awareness of sharing the same attribute with others), connectedness (existence of relationships between different people) and groupness (Golka, 2010). Expanding and accepting such conceptual network may considerably facilitate the analysis of theater shows, which are of autobiographical, documentary nature, follow a long research process, play revisionist and cathartic function through the spectators identifying themselves with personal confessions. What is more, they are produced thanks to regional cooperation, they bring together artists from different countries of former Yugoslavia who experienced breakup of the state, conflicts, formation of new statehoods and attempts to make new self-definitions.

There are several documentary performances which are strongly connected with social and political aspects of the times of its creation, with 'cultural memory'and with autobiographical memory (Tasić, 2010). Such a model is adopted consciously and strategically since, as Paul Ricoeur stated, identity, as revealed in the narrative, is precisely a strange mixture of memories and oblivion (Ricoeur, 2001). A very specific, autobiographical type of memory is a part of the memory relating to the personal past of an individual. It contains memories linked to identity, of both of episodic and semantic nature. It influences activity and establishing of goals; it is embedded in human experience and emotions, helps in creating plans. It defines ,who we are, who we were and, more importantly, who we may become" (Rybak-Korneluk et al., 2016: 960).

The axis of Hypermnesia (Hipermnezija, 2011) is just playing back the recorded traces of psychological experiences. The performance has a fragmentary form, 
it is a kind of mosaic, a combination of technical solutions and individual stories. On the stage there is an international group of actors from Belgrade, Sarajevo and Pristina. Playwrights are Nataša Govedarica and Filip Vujošević from Serbia, and the director Selma Spahić was born in Bosnia and Herzegovina. This complex performance rests on testimonies, memories, emotions of actors who play in it and on what Yugoslavia meant to them, not only as a political and geographical fact but as an intellectual space, among other things, one that shaped their growing up, where they found their loves, experienced good and bad things in life, something that is their own memory module. For this reason, the age diversity among the actors, demonstrates that a common denominator, such as the fact that they were born in the same country, does not imply that they all experience the country in the same way, or that their memories are the same. Some nurture bitterness, of broken illusions, restricted freedoms, while others cherish certain melancholy or sentimental feelings associated with Yugo-nostalgia.

Contemporary identity processes circulate between several poles, namely between disintegration of content and form of cultural systems and the search for new wholes for them; detachment from the local and close territory and the quest for some new 'rootedness' in some specific environment; the mysterious and hybrid relocation of content and forms and the desire to experience them more deeply and to recognize them as a determinant of the behavior of an individual (Golka, 2010). These issues echo among others in the play Patriotic Hypermarketwhich was a part of research project Views: Personal Histories of Serbs and Albanians (carried out in collaboration of Kulturanova, Novi Sad and Qendra Multimedia, Pristina during 2010). Within the framework of the project, 40 individuals of Serbian and Albanian ethnic origin from Kosovo were interviewed about their personal memories of Serbo-Albanian conflicts, their versions of the future and the possibilities of co-habitation. Based on these materials, Milena Bogavac, a dramaturge from Belgrade, and Jeton Neziraj from Kosovo, worked in collaboration to write a documentary post-dramatic text. Dino Mustafić, a director from Sarajevo, worked with the actors and actresses from Belgrade, Pristina, Skopje and Tirana to set up this play for the Bitef Theater in Belgrade. Performers talk about their collective memories and feelings related to childhood, youth, school, friendship, hatred, war, and also share their ideas for future projects. The authors opted for an ironic title and decided to show unpleasant facts from the perspective of so-called ordinary people. The show includes lines in Albanian and Serbian, which gave this project a new dimension. Also, a specific order has been distorted here, making the play especially interesting: Albanians do not play Albanians, and Serbians do not play Serbians - their roles are changeable and fluid. This lack of closure puts the hybrid identity in a situation of limited definiteness and anticipation of what is to come and what is to define the new identity and confirm its nature. 
Another project that clearly belongs to this tradition of socially-engaged theater is Foreign Heart or a Theatrical Debate on Borders (Tuđe srce ili pozorišni traktat o granici, 2016). In this interventional work, the issue of imposed, often illogical divisions is addressed and attempts are made to transcend them. The work discusses not only a national border determining the geographical location of the territory. It turns out that experiencing external and internal boundaries and dealing with the consequences of their existence is an integrating factor here. The director, Dino Mustafić and author of the dramatized script, Biljana Srbljanović, and an international theater company show the multifaceted spatial dimension of the border and a number of cross-border links of socio-cultural nature.

The project on problematic visa regime concerning communication between Kosovo and Bosnia was created thanks to the activities of ART HUB - The center for research and support of scenic art in Sarajevo and funding from the Open Society Foundations B\&H and Kosovo. The project is built on documentary texts, life and institution documents and confessions of artists who explore the issue of the border how this phenomenon functions in their private and professional lives. The physical, political and administrative meaning of a border is as important as the issue of reinforcing stereotypes and prejudices, i.e. imaginary borders. In this interactive event, the actors who say that their freedom, in the broadest sense of the word, is restricted are at the same time co-authors and organize the direction and course of the performance interplaying with the audience. They openly criticize the system which through humiliating procedures curtails their mobility and integration. As an outcome of the teamwork, a text has been produced in which social circumstances and political content affecting communities are shown through the prism of individual personal stories. It is a proof of border permeability.

\section{Conclusion}

Theater undoubtedly functions as „a space for discourse, discussion and memory“ (Duda \& Wiśniewska, 2015: 18). Its specificity is based on „the complex interaction between production and reception, entangled in a movement that can be described as circulation, but only if we understand that it is not possible to go back to the starting point and create a closed circle"(Weber, 2009: 111). The hybridity of theater is linked to mechanisms of generating and practicing cultural and social spaces. The methodologies and theories developed in this field allow to move smoothly between disciplines, established canons, and anachronistic paradigms. This enables a critical view of the strategies for creating history and the past, but also looking ahead towards possible futures. This also applies to the post-Yugoslav region. 
In the research context, this compilation of the matter of performance with the diversity of inspirations (literary, theatrical, filmic, television and musical), construction approaches and practices, and identification processes leads to a communication situation which is extremely interesting for the spectator, where the sense of comfort disappears as well as the possibility to make a simple rationalisation or moral ruling.

The phenomena perceptible in the contemporary sphere of drama and theater, whose basic premise - after all - is encounter and interaction, testify to the pervasion, transfer and combination of elements from various cultures, arts, medias and approaches. This can be perfectly proven by the above examples. We can only believe that artistic and other circumstances will be favorable for the development of new transcultural theater which, using a paraphrase of Jeton Neziraj's words, ,articulates the demands and the needs of the audience, critically reflects upon the past and the present, recognizes its aesthetic and emancipating role, a theater which is open and ready to see above the 'national' topics, a theater that becomes the voice of the weak and of the oppressed" (Neziraj, 2011: 94). It is important for the performative power of theater to challenge stereotypes and change the way people think. That is why this type of projects should be executed on a wider scale and supported in order to meet the requirements of contemporary times.

These undertakings contribute to the extension of transcultural awareness and they are a challenge not only for analyses in theater studies and anthropology, but also socio-political ones. This presentation and main conclusions which can be drawn so far encourage further research in this field.

\section{REFERENCES:}

1. Balakijan, Aram. 2019. „Meet the man who built Belgrade`s theatre of broken dreams where the Yugoslav ideal lived and died“", The Calvert Journal. Retrieved April 15, 2020 from the World Wide Web https://www.calvertjournal.com/features/show/11232/meet-the-man-whobuilt-belgrades-theatre-of-broken-dreams-where-the-yugoslav-ideal-lived-and-died

2. Borowski, Mateusz, M. Kaczmarek, B. Macias, W. Puś, M. Sugiera \& W. Ziemilski. 2012. „Medium czy gadżet? Wideo w teatrze“, Didaskalia, 107, 42-49.

3. Chaberski, Mateusz. 2016. „Teatralność jako doświadczenie proteuszowe w hybrydycznych formach sztuki najnowszej“, Widok. Teorie i praktyki kultury wizualnej, 15, 1-16.

4. Crimp, Douglas. 1980. „The Photographic Activity of Postmodernism“, October, vol. 15, Winter, 91-101.

5. Deardorff, Darla K. 2008. „Intercultural Competence“; In: V. Savicki (Ed.): Developing Intercultural Competence and Transformation. Virginia: Stylus Publishing.

6. Duda, Artur \& M. Wiśniewska. 2015. „Teatr wśród mediów - wyzwania i propozycje badawcze“; In: A. Duda, M. Wiśniewska, B. Oleszek (Eds.): Teatr wśród mediów. Toruń: Wydawnictwo Naukowe Uniwersytetu Mikołaja Kopernika.

7. Fischer-Lichte, Erika. 2010. „Interweaving Cultures in Performance: Different States of Being In-Between", Textures. Online Platform for Interweaving Performance Cultures. Retrieved April 15, 2020 from the World Wide Web http://www.textures-platform.com/?p=961 
8. Fischer-Lichte, Erika. 2014. The Routledge Introduction to Theatre and Performance Studies. M. Arjomand \& R. Mosse (Eds.), Trans. M. Arjomand. London: Routledge.

9. Golka, Marian. 2010. Imiona wielokulturowości. Warszawa: Muza.

10. Greenblatt, Stephen. 2009. „A mobility studies manifesto“; In: S. Greenblatt, I. G. Županov, R. Meyer-Kalkus, H. Paul, P. Nyíri \& F. Pannewick (Eds.): From Cultural Mobility: A Manifesto. Cambridge: Cambridge University Press.

11. Heiser, Jörg. 2010. „Pick \& Mix: State of the Art“, Frieze, 133, 33-41.

12. Neziraj, Jeton. 2011. „Theatre in Kosovo. The challenges in the new state“; In: J. Thompson, J. Neziraj (Eds.) Theatre and Nationalism. Pristina: Qendra Multimedia.

13. Pavis, Patrice. 1998. Stownik terminów teatralnych, Ed. and Trans. S. Świontek. Wrocław: Zakład Narodowy im. Ossolińskich, 21.

14. Rewers, Ewa. 2003. „Transkulturowość czy glokalność? Dwa dyskursy o kondycji ponowoczesnej“, ER(R)GO. Teoria-Literatura-Kultura, 1 (6), 53-65.

15. Ricoeur, Paul. 2001. „Większość była gapiami. Z Paulem Ricoeurem rozmawia Jacek Żakowski“, Gazeta Wyborcza, 23.06., 11.

16. Rybak-Korneluk, Anna, H. Wichowicz, K. Żuk \& M. Dziurkowski. 2016. „Pamięć autobiograficzna i jej znaczenie w wybranych zaburzeniach psychicznych“, Psychiatria Polska, 50(5), 959-972.

17. Sordyl, Alina. 2011. „Adaptacja jako twórcza praktyka w polskim teatrze współczesnym. Krystian Lupa - Krzysztof Warlikowski - teatr krytyczny“, Postscriptum Polonistyczne, 2 (8), 43-60.

18. Tasić, Ana. 2012. „Dokumentarno pozorište kao prostor preispitivanja transkulturalnog sećanja i identiteta: slučaj predstava Hipermnezija i Rođeni u YU“. Retrieved April 15, 2020 from the World Wide Webhttp://www.fdu.edu.rs/uploads/uploaded files/_content_strane/2012 ana tasic.pdf

19. Weber, Samuel. 2009. Teatralność jako medium, Trans. J. Burzyński. Kraków: Wydawnictwo Uniwersytetu Jagiellońskiego.

20. Welsch, Wolfgang. 1998. „Transkulturowość. Nowa koncepcja kultury“; In: R. Kubicki (Ed.): Filozoficzne konteksty rozumu transwersalnego. Wokót koncepcji Wolfganga Welscha, Trans. B. Susła \& J. Wietecki. Poznań: Wydawnictwo Fundacji Humaniora.

21. Welsch, Wolfgang. 1999. „Transculturality—the Puzzling Form of Cultures Today“; In: M. Featherstone \& S. Lash (Eds.): Spaces of Culture: City, Nation, World. London: Sage.

22. Welsch, Wolfgang. 2004. „Tożsamość w epoce globalizacji - perspektywa transkulturowa“; In: K. Wilkoszewska (Ed. and Trans.): Estetyka transkulturowa. Kraków: Universitas.

\section{Transkulturna hibridnost u postjugoslovenskom pozorištu ${ }^{4}$}

Apstrakt: Postjugoslovenska makroregija je dinamična i složena zona u kojoj se manifestuju savremene tenzije između kulturne homogenizacije i kulturne heterogenizacije. Ona sadrži idiom višejezičnosti, multietničnosti, multireligioznosti i komplikovanih procesa identiteta i stabilnosti. Nakon prisilnog „,zajedničkog života“ u okviru jugoslovenske federacije i njenog raspada nakon toga, obnovljeni su produktivni pregovori, te „zajednički život“, pa čak i međusobna saradnja. To je naročito uočljivo u domenu pozorišta, koje podrazumeva susret i interakciju. Početkom dvadeset prvog 4 Tekst je rezultat istraživačkog projekta br. 2017/24 / C / HS2 / 00436, finansiranog od strane Nacionalnog naučnog centra Poljske. 
veka, na prostoru bivše Jugoslavije, pojave koje potvrđuju transkulturnu blisku saradnju unutar ove (hiper)produkcije, postaju sve učestalije. I zaista, međusobno prožimanje kultura, umrežavanje, protok kreativnih, estetskih i filozofskih ideja nastalih iz različitog kulturološkog miljea, mobilnost umetnika, korišćenje savremenih komunikacionih kanala, kao i prevođenje, dovode do stvaranja novih, hibridnih kvaliteta.

Trenutno se u regionu primećuje sve veći broj takvih oblika javnog pozorišnog izraza; oni nastaju usled mešanja kultura, povezivanja dokumentarca i fikcije, intermedijalni su, pokretni, višejezični i fluktuiraju između područja umetnosti i društvenog života. Eksperimentalni scenski projekti koje su kreirali Milena Bogavac i Kokan Mladenović (iz Srbije) ili Jeton Neziraj (s Kosova), zatim predstave u režiji Boruta Šeparovića (iz Hrvatske), Jerneja Lorencija (iz Slovenije), Selme Spahić i Dina Mustafića (iz Bosne i Hercegovine) deluju kao medijum posebno predodređen za istraživanje problema identiteta - hibridni, projektovani, performativni, kontekstualni, prilagodljivi i precizni u odnosima s Drugošću. Stoga, ovi projekti osporavaju zvanične, homogenizujuće diskurse. Izraz 'hibridnost' ovde će označavati metaforu - formalnu strukturu koja predstavlja spoj kuluturnih kodova i kombinaciju različitih modela kreativnog izražavanja.

Kao odgovor na zahtev za pronalaženjem odgovarajućeg rešenja za tumačenje ovih procesa, metodološke veštine biće obogaćene kategorijom transkulturalnosti koju je predložio Volfgang Velš, nemački teoretičar postmodernizma. Ova opcija sadrži modernu viziju otvorene kulture koja generiše umetničke predloge koji zahtevaju određenu vrstu prijema.

Ključne reči: hibridnost, transkulturalnost, pozorište, postjugoslovenski region, identitet. 